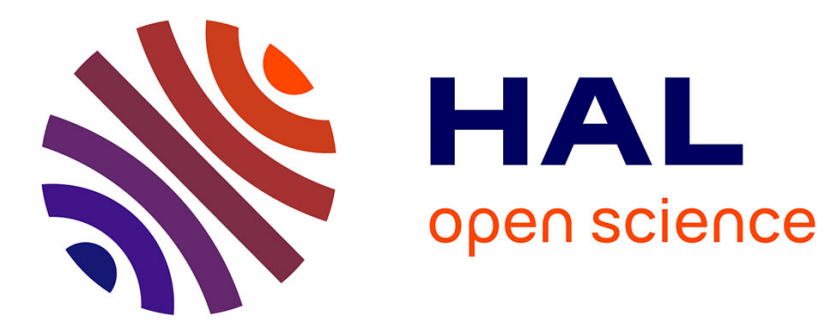

\title{
MATERIALS AND INTERFACES \\ CHARACTERIZATION BY MICRO-RAMAN SPECTROSCOPY
}

P. Huong

\section{> To cite this version:}

P. Huong. MATERIALS AND INTERFACES CHARACTERIZATION BY MICRO-RAMAN SPECTROSCOPY. Journal de Physique IV Proceedings, 1991, 01 (C6), pp.C6-151-C6-162. 10.1051/jp4:1991624 . jpa-00250709

HAL Id: jpa-00250709

https://hal.science/jpa-00250709

Submitted on 1 Jan 1991

HAL is a multi-disciplinary open access archive for the deposit and dissemination of scientific research documents, whether they are published or not. The documents may come from teaching and research institutions in France or abroad, or from public or private research centers.
L'archive ouverte pluridisciplinaire HAL, est destinée au dépôt et à la diffusion de documents scientifiques de niveau recherche, publiés ou non, émanant des établissements d'enseignement et de recherche français ou étrangers, des laboratoires publics ou privés. 


\title{
MATERIALS AND INTERFACES CHARACTERIZATION BY MICRO-RAMAN SPECTROSCOPY
}

\author{
P.V. HUONG \\ Laboratoire de Spectroscopie Moléculaire et Cristalline, U.R.A. 124 - C.N.R.S., Université \\ de Bordeaux I, 351 Cours de la Libération, F-33405 Talence, France
}

\begin{abstract}
Several aspects of Raman and micro-Raman spectroscopy are shown and applied for the characterization of semiconductor materials and bi-layers of semiconductor on semiconductor and insulator on semiconductor.

As a molecular technique, Raman spectroscopy will inform not only on the nature of elements but also on chemical bonds between atoms.

Raman spectroscopy also permits the studies of disordered or amorphous materials.

Based on the anisotropy in Raman scattering, the determination of the orientation of surfaces and thin layers becomes also easy.

Micro-Raman spectroscopy, with a spatial resolution of the order of $1 \mathrm{\mu m}^{2}$, allows the study of heterogenous or very small materials. This technique is very helpful in the determination of heterogeneity, stress and gradient in semiconductors.

On step-etched or bevelled samples of a bi-layer, micro-Raman spectroscopy helps to examine the epitaxy quality of the deposit versus its thickness and also to detect eventual chemical bonds between deposit and substrate.
\end{abstract}

\section{1 - INTRODUCTION}

In materials sciences, final application is of course a very important end. But this stage is necessarily preceeded by syntheses and characterization steps and the explanation of mechanisms and properties.

Morphological and elemental characterization methods are widely used for new advanced materials. Vibrational spectroscopy, especially Raman spectroscopy has the advantage to be a molecular method. By the examination of Raman frequencies, intensities and band shapes, one can deduce the nature and the force of chemical bonds linking the atoms in the examined samples [1-6]. As these spectral characteristics change with the interaction between a group of atoms of the system; a study of these changes can inform on the nature and the forces of the interaction.

When approaching the exciting light energy to that of a chromophore (Fig.1), resonance Raman effect can appear and gives an intensity enhancement reaching more than one million of time [7,8]. In consequence, the concentration or amount of submitted sample can be reduced by the same factor.

In addition, by coupling an optical microscope to a Raman spectrometer (Fig.2), spatial resolution can be reduced to less that $1 \mathrm{\mu m}^{2}$. Thus, small samples, as well as differents spots of a sample or heterogenous materials can give specific Raman spectra by this non destructive technique [9]. 
In this paper, we shall present an application of micro- Raman spectroscopy in the studies of materials and interfaces interesting for particular microelectronics.

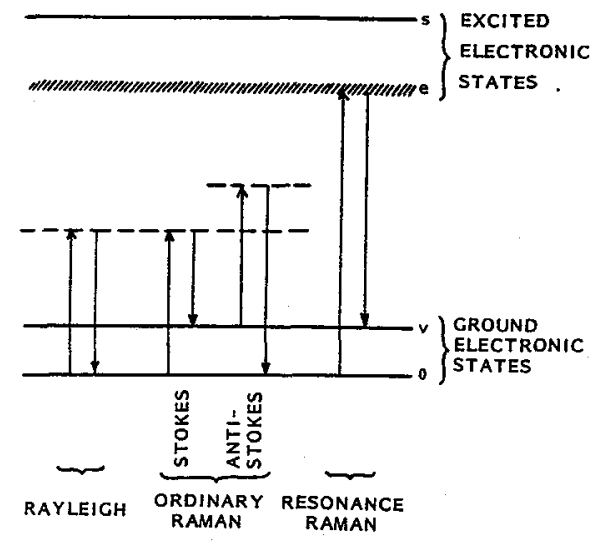

Fig.1 - Energy scheme in light scattering.

\section{2 - SEMICONDUCTORS : STRUCTURES AND RAMAN SPECTRA}

\section{1 - Phonons and elements identification.}

For single element materials, the phonon frequencies can inform on the nature of the element.

For covalent materials with cubic diamond structure such as silicium or germanium, the optic modes are degenerate and only one first-order mode is active in Raman scattering. For crystalline silicon, the Raman first phonon appears at $521 \mathrm{~cm}^{-1}$, while for germanium it is located at $300 \mathrm{~cm}^{-1}$ and for diamond itself, a strong Raman peak is recorded at $1331 \mathrm{~cm}^{-1}$. The heavier oscillator vibrates at the lower frequency.

For diatomic $\mathrm{AB}$ species, the frequency of vibration along the chemical bond is given, in the harmonic approximation, by

$$
v=\frac{1}{2 \pi \mathrm{c}} \sqrt{\frac{K}{\mu}}
$$

where $K$ is the force constant, $\mu$ the reduced mass $1 / \mu=1 / m_{A}+1 / m_{B}, c$ the velocity of light ; $m_{A}$ and $m_{B}$ are the atomic masses of $A$ and $B$ atoms.

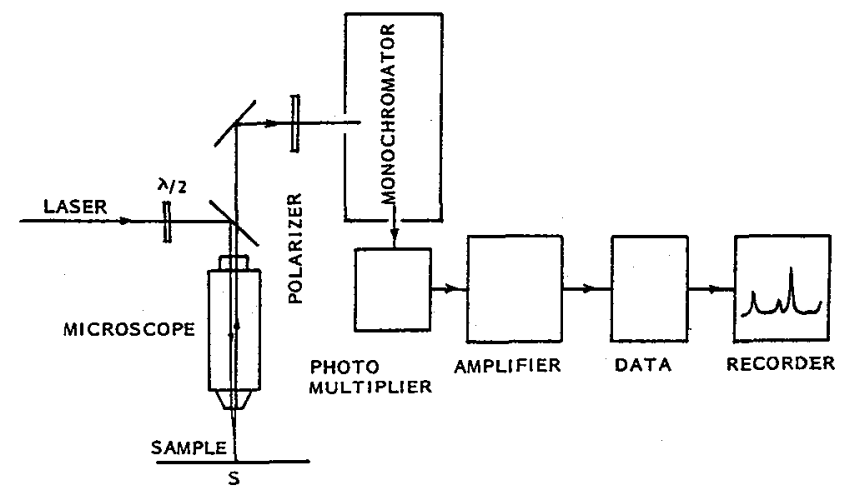

Fig.2 - Scheme of a micro-Raman spectrometer. 
In fact, in the solid state, a motion of each atom induces the motion of its neighbouring atoms ; thus, a vibration is not strictly localized on a chemical bond but represents an oscillation or phonon of the whole solid network : all vibrations in a unit cell and the three rotations of the unit cell become optic vibrations of the crystal, while the three translations of the unit cell remain as translations or acoustic modes of the crystal. The latter modes have zero frequency in the Brillouin zone centre. The oscillation mode is called longitudinal or transverse when the polarization or electric dipole moment of the medium is parallel or perpenducular to the phonon propagation direction or wave vector in the medium.

In diamond structure materials, the two TO (transverse optic) and LO (longitudinal optic) modes coïncide by degeneracy.

\section{2 - Bi-phonons, multiphonons.}

In fact, the harmonic approximation is only a simplifying treatment, as on a Raman spectrum of a solid material, not only first order phonon is observed, but biphonons, even multiphonons can also appear. Such is the case of crystalline silicon which shows first order phonon at $521 \mathrm{~cm}^{-1}$, bi-phonons around $1000 \mathrm{~cm}^{-1}$ and tri-phonons near $1500 \mathrm{~cm}^{-1}$ (Fig.3).

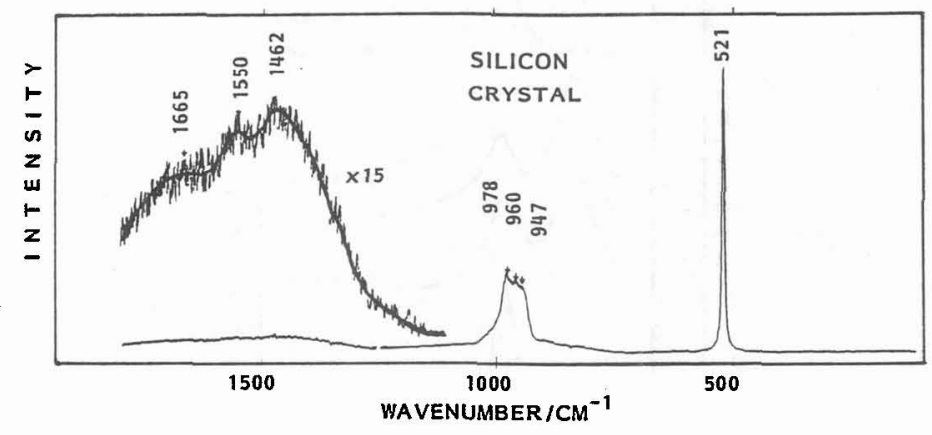

Fig.3 - Bi and tri-phonons of crystalline silicon.

\section{3 - Zinc blende structure materials}

For non centro-symetric crystals with zinc blende structure such as GaAs, InP, etc ... the degeneracy is split and both TO and LO modes can appear in Raman scattering (Fig.4).

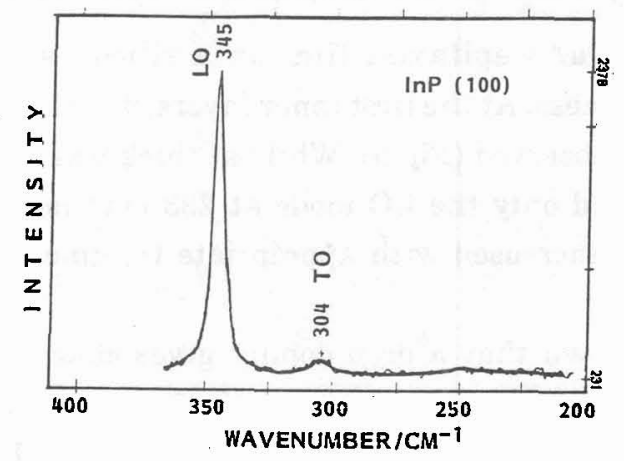

Fig.4 - TO and LO modes in InP. 
The relative intensity of these two phonons depends on the orientation, on the disorder or on the doping [10-15].

\begin{tabular}{|c|c|c|}
\hline Materials & TO & LO \\
\hline ZnS & 273 & 351 \\
ZnSe & 205 & 250 \\
ZnTe & 177 & 205 \\
GaAs & 269 & 292 \\
GaP & 367 & 403 \\
GaSb & 231 & 241 \\
InP & 304 & 345 \\
\hline
\end{tabular}

TABLE I - Transverse and longitudinal optic modes, in $\mathrm{cm}^{-1}$, of zinc blende structure semidonductor crystals [16].

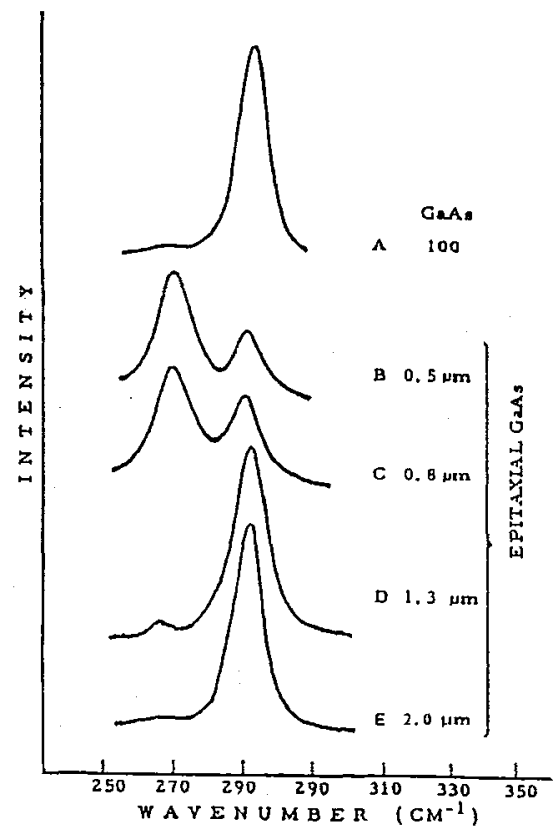

Fig.5 - TO and LO modes of GaAs at various thicknesses.

For instance, a GaAs epitaxial film on a silicon substrate does not give good orientation at every thichness. At the first inner layers, due to lattice mismatch, both TO and LO Raman phonons are observed (Fig.5). While at thickness $\mathrm{h}$ igher than $1.3 \mu \mathrm{m}$ the layer becomes good oriented and only the LO mode at $293 \mathrm{~cm}^{-1}$ is observed [17]. Of course, the quality of the epitaxy is increased with appropriate treatment of the substrate before the deposition.

It is also well-known that $n$ or $p$ doping gives characteristic modifications of the Raman spectrum of III.V semiconductors, in particular resonant conditions can be realized which gives rise to spectral features due to coupled plasmons-LO phonons [13]. 


\section{4 - Effect of charge}

Among dopants in inclusion or partners in semiconductors, oxygen is frequently present. Raman spectroscopy can help to detect it. The frequency of this homopolar diatomic species is very sensitive to the effect of charge [18] on the oscillator (Table II).

\begin{tabular}{|c|c|c|c|c|}
\hline & $\mathrm{O}_{2}{ }^{+}$ & $\mathrm{O}_{2}$ & $\mathrm{O}_{2}$ & $\mathrm{O}_{2}{ }^{2-}$ \\
\hline $\mathrm{v}\left(\mathrm{cm}^{-1}\right)$ & 1865 & 1580 & 1097 & $\sim 766$ \\
\hline $\mathrm{K}(\mathrm{m}$ dyn $/ \AA)$ & 16.39 & 21.76 & 5.67 & $\sim 2.76$ \\
\hline
\end{tabular}

TABLE II - Frequencies and force constants of homopolar diatomic oxygens.

\section{5 - Disorder, stress, amorphicity}

Although vibrational spectroscopy is only an indirect method for the structural determination, this technique presents some advantage in comparison to other direct diffraction methods, in the studies of amorphous or disordered materials [19].

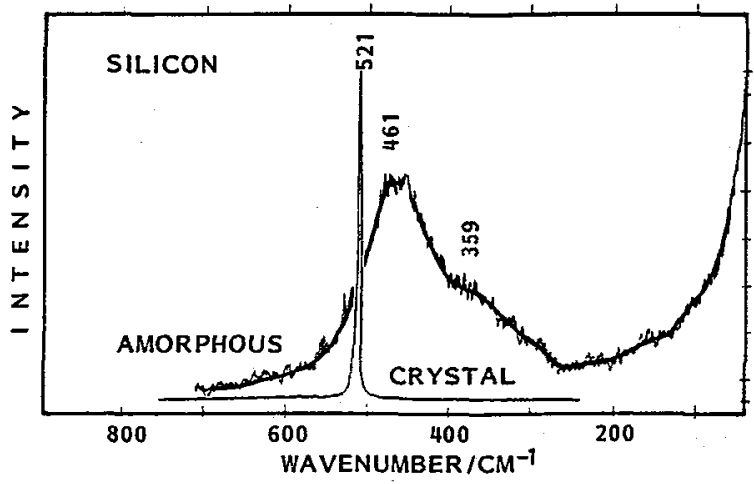

Fig.6 - Raman spectrum of amorphous silicon.

For silicon, it is not only easy to distinguish crystalline silicon from amorphous silicon (Fig.6) but one is able to follow several degrees of amorphicity by measuring the frequency, varying from $461 \mathrm{~cm}^{-1}$ in totally amorphous, to $521 \mathrm{~cm}^{-1}$ in bulk crystalline silicon. Of course, the band width at half intensity or the band shape can also help to understand the dynamic aspect of the silicon motion inside of the disordered network. This technique is particularly helpful in the characterization of a silicon annealed by laser (1).
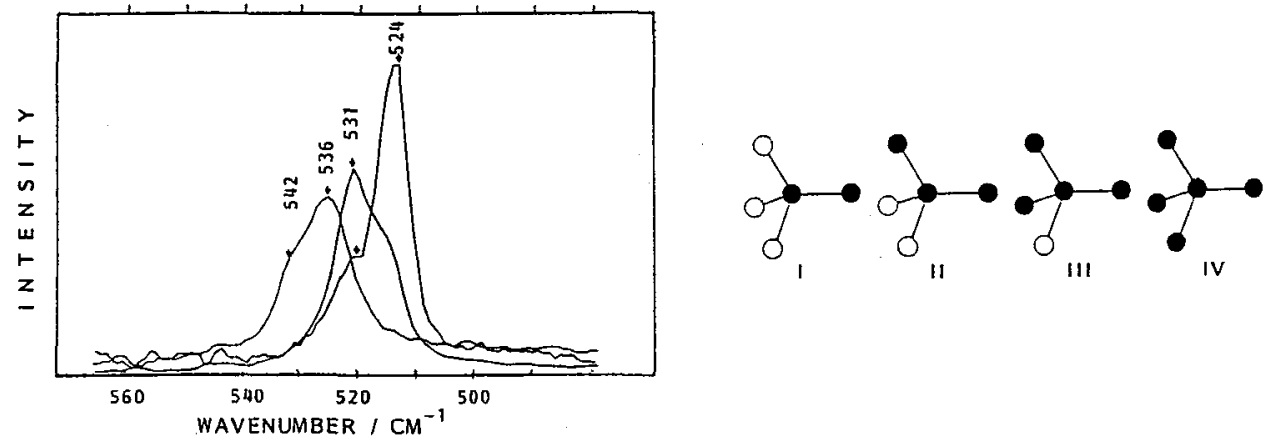

Fig.7 - Raman spectra of small silicon aggregates. 
Recently, small aggregates, silicon dimers, trimers, etc... in a silicon-carbide matrix has been shown [22] as having characteristic Raman frequency, higher than $521 \mathrm{~cm}^{-1}$ of bulk silicon, from 524 to $542 \mathrm{~cm}^{-1}$, the latter corresponds to Si-Si dimers (Fig.7).

The stretching frequency is also sensitive to the stress in the material [20].

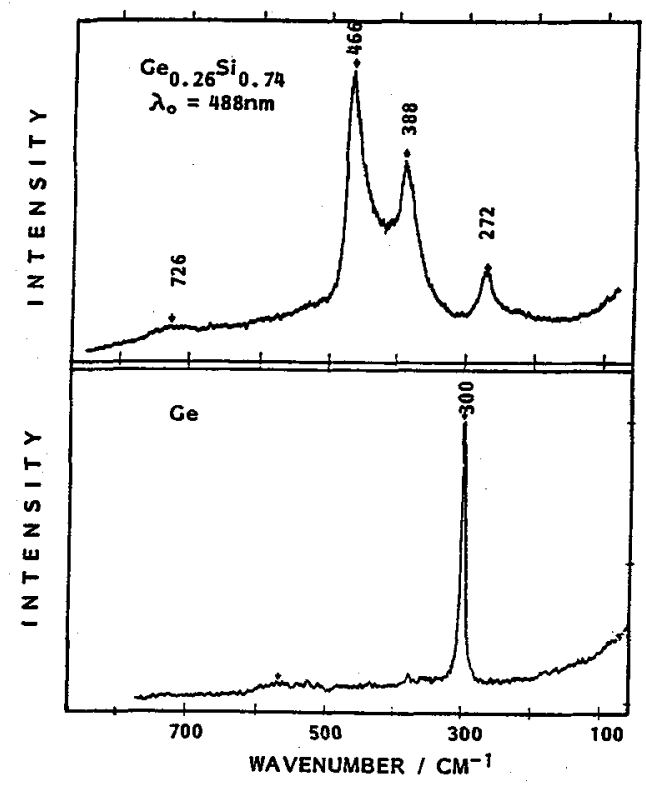

Fig.8 - Raman spectrum of Ge-Si alloy.

\section{3 - CHEMICAL BONDS IN SEMICONDUCTORS.}

\section{1 - Heteroatom chemical bonds.}

While many techniques can inform on the nature of the elements of a material sample, Raman spectroscopy can also give the evidence of chemical bonds between atoms, either the sample is in the gazeous, liquid or solid state.

The Raman spectrum of a $\mathrm{Ge}_{0.74} \mathrm{Ge}_{0.26}$ alloy (Fig.8), shows not only bands characteristic of Si-Si bond at $466 \mathrm{~cm}^{-1}$ and $\mathrm{Ge}-\mathrm{Ge}$ bond at $272 \mathrm{~cm}^{-1}$ but also Ge-Si bond at

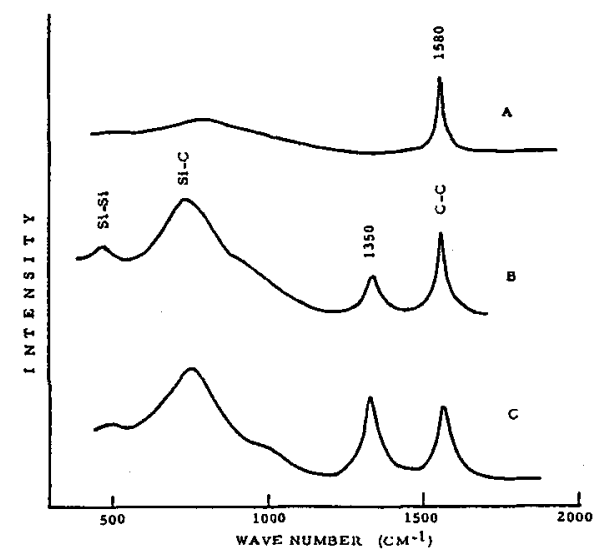

Fig.9 - Raman spectrum of carbon impurity in silicon. 
$388 \mathrm{~cm}^{-1}$ [21]. In addition, the frequency and the relative intensity of these bands compared to those of pure $\mathrm{Si}\left(521 \mathrm{~cm}^{-1}\right)$ and $\mathrm{Ge}\left(300 \mathrm{~cm}^{-1}\right)$ also indicate the aggregate composition and geometry of the alloy.

\section{2 - Impurities in silicon}

Among the impurities which are present in silicon, carbon is frequently found. Raman spectroscopy is an easy technique to detect it, not only for its identification, but also for the characterization of its degree of graphitization $[22,23]$, as amorphous carbon possesses two Raman peaks at 1350 and $1580 \mathrm{~cm}^{-1}$, while graphite of high graphitization degree presents only one $\mathrm{C}-\mathrm{C}$ band at $1580 \mathrm{~cm}^{-1}$. Chemical bonds between $\mathrm{C}$ and $\mathrm{Si}$ are also detected (Fig.9).

\section{3 - High temperature semiconductors : diamond.}

Diamond films are now obtained by simple chemical vapour deposition methods at low temperature and pressure.

By Raman spectroscopic examination, two kinds of diamond films can be distinguished. One of them has the Raman peak characteristic of diamond (Fig.10), with its

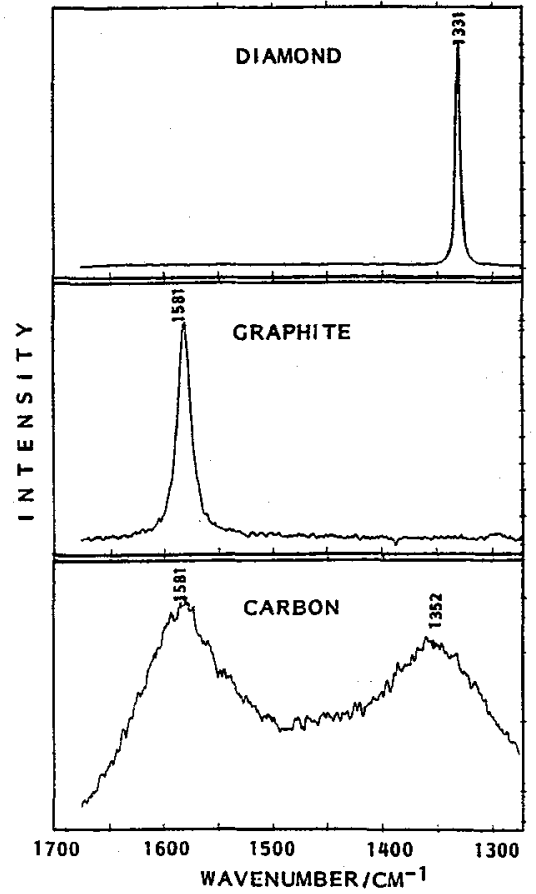

Fig.10 - Raman spectrum of diamond

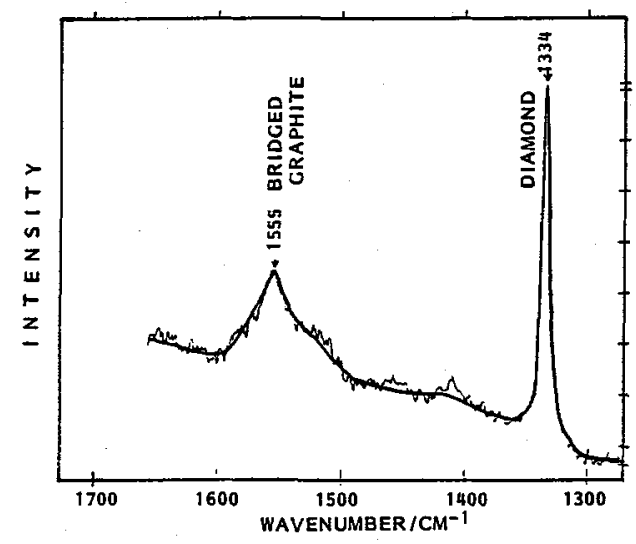

Fig.11 - Raman spectrum of "diamite"or "bridged graphite".

frequency varying from 1331 to $1345 \mathrm{~cm}^{-1}$ and half-band-width from 1.7 to $15 \mathrm{~cm}^{-1}$ depending on its distorsion from the ideal cubic structure. The second series are diamond-like and has its C-C "stretching" frequency around $1540 \pm 20 \mathrm{~cm}^{-1}$ (Fig.11). This corresponds to a new structure named "diamite" or "bridged graphite" where some carbon atoms get out of the graphitic layer making possible the bonding between adjacent layers [23]. 


\section{4 - Phase conversions}

In the series of new Y-Ba-Cu-O copper oxides, $\mathrm{YBa}_{2} \mathrm{Cu}_{3} \mathrm{O}_{6}$ is semiconductor. When the vacancies in its structure are partially occupied by oxygen, the material becomes a superconductor. With $\mathrm{YBa}_{2} \mathrm{Cu}_{3} \mathrm{O}_{7}$, the $\mathrm{T}_{c}$ reaches $92 \mathrm{~K}$. Raman spectroscopy is an easy method to identify them (Fig.12). In addition, the Raman frequency vH corresponding mainly to the stretching of the $\mathrm{Cu}^{2} \mathrm{O}^{1}$ bonds along the $c$ axis allows a rapid evaluation $[6,24,25]$ of the oxygen content in $\mathrm{YBa}_{2} \mathrm{Cu}_{3} \mathrm{O}_{\mathrm{x}}$ :

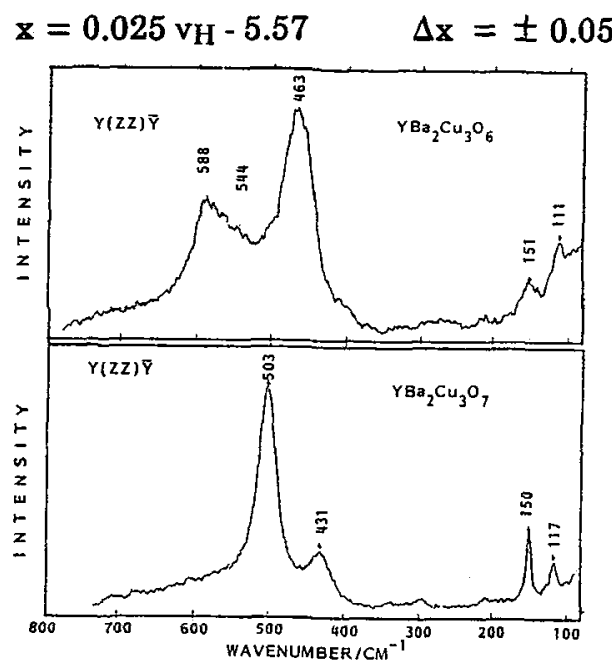

Fig.12 - $\mathrm{ZZ}$ polarized Raman spectra of $\mathrm{YBa}_{2} \mathrm{Cu}_{3} \mathrm{O}_{6}$ and $\mathrm{YBa}_{2} \mathrm{Cu}_{3} \mathrm{O}_{7}$.

In $\mathrm{YBa}_{2} \mathrm{Cu}_{3} \mathrm{O}_{7}\left(\mathrm{Y}_{123}\right)$, there is one $\mathrm{Cu}^{1} \mathrm{O}^{4}$ layer between the two $\mathrm{BaO}^{1}$ layers. Very recently a new and very promissing material presents two $\mathrm{Cu}^{1} \mathrm{O}^{4}$ layers between the two $\mathrm{BaO}^{1}$ layers : $\mathrm{YBa}_{2} \mathrm{Cu}_{4} \mathrm{O}_{8}\left(\mathrm{Y}_{124}\right)$ (leading to two Raman $\mathrm{Cu}-\mathrm{O}$ bands in polarized spectrum along $c$ axis (Fig.13). The conversion of $\mathrm{Y}_{124}$ into $\mathrm{Y}_{123}$ is easily followed by Raman spectroscopy : the frequency shifts also help to explain the change in bond length and in the size of their unit cell, in particular in the $c$ axis.

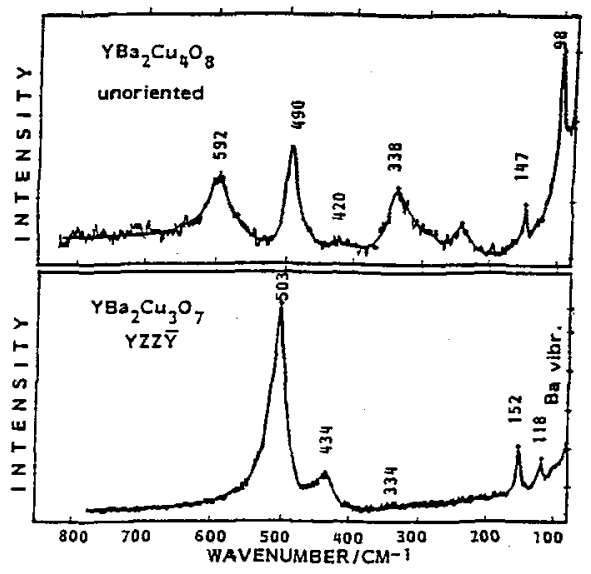

Fig.13 - Raman spectrum of $\mathrm{YBa}_{2} \mathrm{Cu}_{4} \mathrm{O}_{8}$. 


\section{4 - ORIENTATION OF SURFACES AND THIN LAYERS}

Based on strong anisotropy frequently existing in Raman scattering (Fig.14), the orientation of a surface on thin layer can be determined $[25,27-29]$ by recording its perpendicular back-scattering and by referring to a calibration made with polarized Raman spectra of known oriented single crystals.

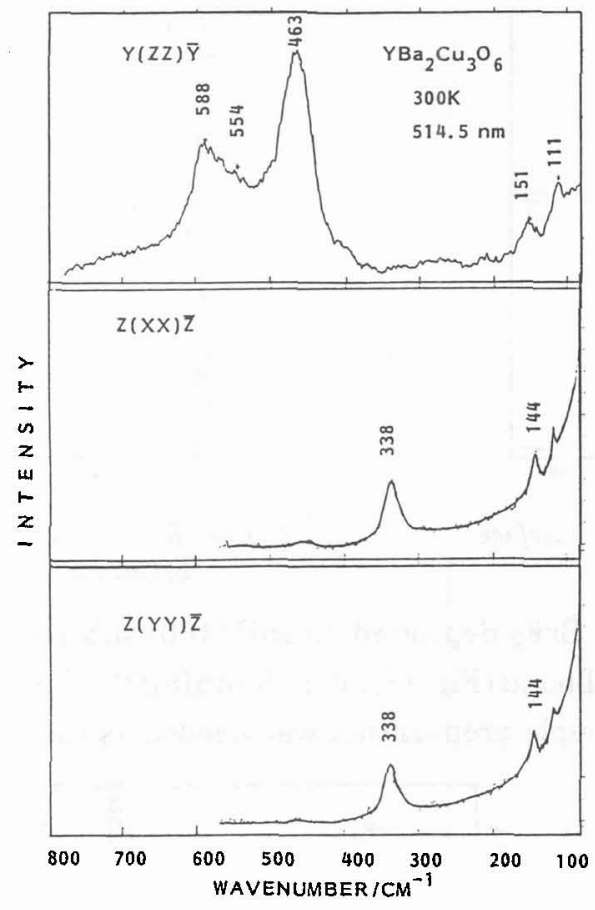

Fig.14 - Polarized Raman spectra of $\mathrm{YBa}_{2} \mathrm{Cu}_{3} \mathrm{O}_{6}$ single crystal.

\section{5 - INTERFACE - CHEMICAL BONDING BETWEEN DEPOSIT AND SUBSTRATE}

In bi-layers of semiconductor on semiconductor or semiconductor on insulator, the nature of the interface depends strongly on the lattice mismatch and on the preparation conditions. Raman spectroscopy can help to detect structural modifications around the interface and eventually new chemical bonds which can occur between deposit and substrate by applying the method described above on step-etched or bevelled samples (Fig.15).

With GaAs on Ge [17], both Ga-Ge and As-Ge bonds were shown (Fig.16). With GaAs on Si [11,30], only As-Si bonds are detected (Fig.17).

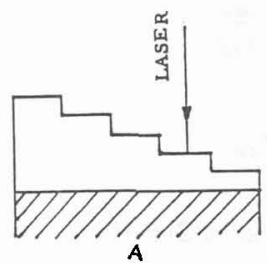

A

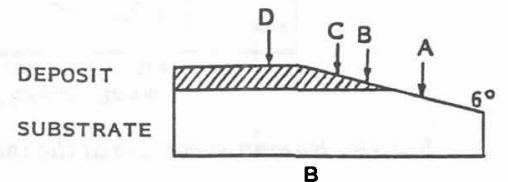

Fig.15-Step-etched and bevelled bi-layers. 


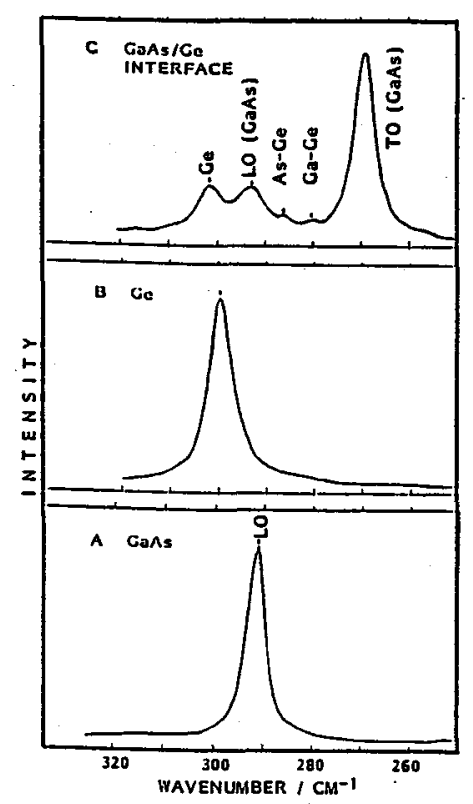

Fig.16 - Raman spectrum at the interface of $G a A s / G e$.
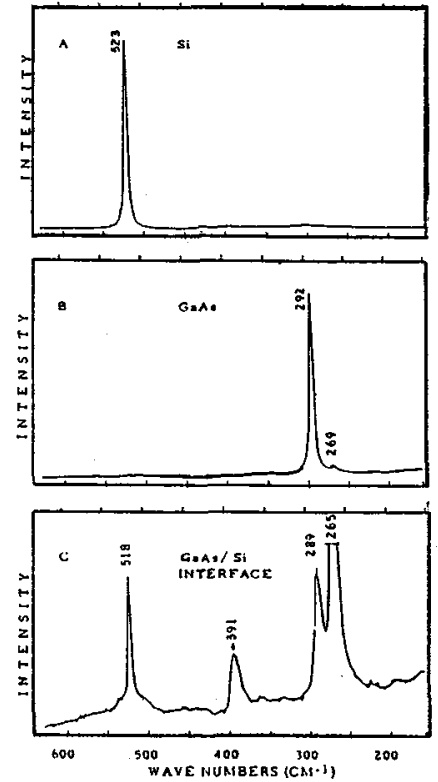

Fig.17 - Raman spectrum at the interface of GaAs/Si.

For insulator $\mathrm{SrF}_{2}$ deposited on $\operatorname{InP}(100)$ substrate [31], P-F seemed to be the only one existing chemical bond (Fig.18). For obtaining the Raman spectrum of the interface in this case, no further sample preparation was needed as the insulator $\mathrm{SrF}_{2}$ is transparent to the laser used.

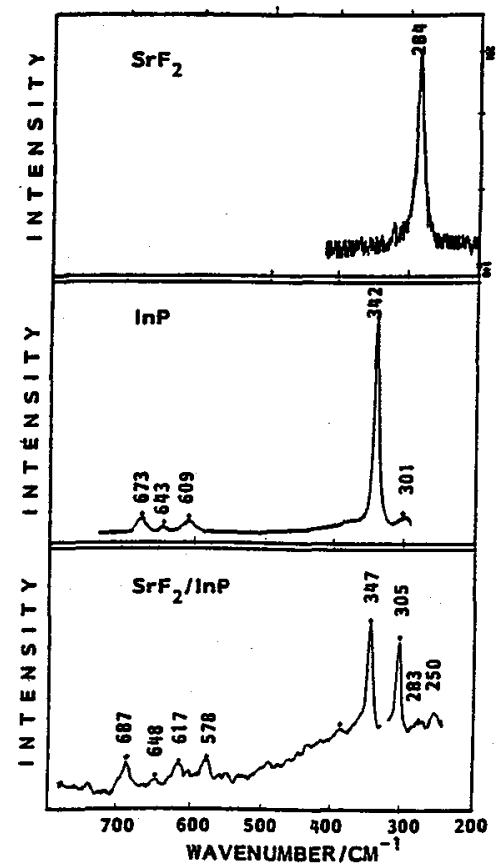

Fig.18 - Raman spectrum at the interface of $\mathrm{SrF}_{2} / \mathrm{In} P$. 


\section{6 - CONCLUSION}

Some above examples illustrate the ability of Raman and micro-Raman in the characterization of semiconductor bulk materials, surfaces and interfaces.

The technique informs not only in the nature of the elements, but also on the chemical bonds between atoms. It presents also the advantage in the studies of amorphous and disordered materials.

Due to high anisotropy observed in Raman polarization, the determination of the orientation of a surface or thin layer becomes easy.

Finally, thanks to the spatial resolution of the order of $1 \mu^{2}$ of micro-Raman technique, the studies of heterogenous or very small samples, as well as that of stress or gradient become also easy.

Acknowledgements. A grant from the Indo-Fench Centre for the Promotion of Advanced Research is appreciated.

\section{REFERENCES}

1 "Raman Spectroscopy : Linear and non Linear". J.LASCOMBE, Pham V. HUONG, (Eds), Wiley, Chichester, New-York, 1982.

2 "Le Silicium".

Pham V. HUONG, (Ed.), Masson, Paris, 1983.

3 "Le Silicium à finalité microélectronique et photovoltaïque" (Tome I). Pham V. HUONG, (Ed.), Masson, Paris, 1986.

4 "Le Silicium à fỉnalité microélectronique et photovolatique" (Tome II). Pham V. HUONG, (Ed.), Masson, Paris, 1987.

5 Pham V. HUONG, in "Lasers and Applications", H.D.Bist and J.S.Goela (Eds)., Tata McGraw-Hill, Bombay 1984.

6 Pham V .HUONG, in "Analysis of Micro-electronic Materials and Devices" M.Grasserbauer, H.W.Werner (Eds).Wiley, Chichester/New-York, 1991.

7 P.V. HUONG, in "Vibrational Spectra and Structure". J.R.Durig Ed., Elsevier, New-York, Amsterdam, 1980.

8 Pham V. HUONG,in "Reviews on Analytical Chemistry". L.Niinisto Ed., Akademia Kiado, Budapest 1982, 209.

9 P.V.HUONG, A.L.VERMA, J.P.CHAMINADE, L.NGANGA, J.C.FRISON, Materials Science and Engineering, 1990, B5, 255.

10 A.FREUNLICH, A.LEYCURAS, J.C.GRENET, C.VERIE, Pham V.HUONG, Appl.Phys.Lett., 1987, 51, 1352.

11 P.V. HUONG, A.LEYCURAS, A.FREUNDLICH, Raman Spectroscopy, R.J.H.Clark, D.A.Long Eds., Wiley, Chichester/New York, 1988, p.393

12 Pham V. HUONG, Materials Sci. \& Engineering, 1991,

13 G.ABSTREITER, M.CARDONA, A.PINCZUK, in "Light Scattering in Solid IV", M.Cardona, G.Guntherodt (Eds), Springer, Berlin 1984, p.5. 
14 B.A.WEINSTEIN, G.J.PIERMERINI, Phys.Lett., 48A (1974) 14.

15 B.TROMMER, H.MULLER, M.CARDONA, P.VOGT, Phys.Rev. B21 (1980) 4869.

16 B.A.WEINSTEIN, R.ZALLEN, in "Light Scattering in Solid IV", M.Cardona, G.Guntherodt (Eds), Springer, Berlin 1984, p.463.

17 P.V. HUONG, A.LEYCURAS, Thin Solid Films, 1990, 184, 423.

18 K.NAKAMOTO, in "Infrared and Raman spectra of Inorganic compounds", Wile, New York, 1978.

19 Pham.V. HUONG, J.L.VUOTTO, Ann.Chim.Paris, 1986, 11, 683.

20 J.L.VUOTTO,J.DEVAURE, P.V. HUONG, Ann.Chim., Paris, 1986, 11, 667.

21 G.VILLELA, Pham V. HUONG, J.L.VUOTTO, Ann.Chim., Paris, 1987, 12, 445.

22 P.V. HUONG, O.SECOND, P.GENTIIINI, R.CAVAGNAT, Applied Surface Sci., 1989, 43, 256.

23 Pham V. HUONG, Diamond and Related Materials, 1991, 1,33.

24 L.NGANGA., Pham V. HUONG, J.P.CHAMINADE, P.DORDOR, K.FRÖLICH, M.JERGEL,

J.Less.Common Metals, 1990, 164 \& 165, 208-214.

25 Pham V.HUONG,

J.Less.Common Metals, 1990, 164 \& 165, 1193-1200.

26 P.V. HUONG, J.P.CHAMINADE, J.C.FRISON, Y.K.PARK, J.C.PARK, K.H.KIM, J.S.PARK,

High temperature superconductor thin-films. Properties and applications.

L.Correra (Ed), Elsevier, Amsterdam, 1991

27 P.V.HUONG,

High temperature superconductor thin-films. Properties and applications.

M.D.Crescenzi (Ed), Elsevier, Amsterdam, 1991,

28 P.V. HUONG, J.C.BRUYERE,.

in "Modern Aspects of Superconductivity", R.Suryanaryanan (Ed.),

I.I.T.T., Paris, 1989, p.149

P.V. HUONG, J.C.BRUYERE, E.BUSTARRET, P.GRANCHAMP, Solid State Comm., 1989, 72, 191.

30 P.V. HUONG, P.BOUTINAUD, S.KAZAOUI, A.LEYCURAS, Microbeam Analysis, San Francisco Press, 1988, 23rd, 167.

31 P.V.HUONG, E.OLLIER, S.DELAVOYE, R.CAVAGNAT, B.MOMBELLI, A.S.BARRIERE, A.L.VERMA,

Non stoechiometry in semiconductors, K.J.Backmann, H.L.Hwane (Eds), Elsevier, Amsterdam, 1991. 